\title{
Poor survival is associated with the methylated degree of zinc-finger protein 545 (ZNF545) DNA promoter in gastric cancer
}

\author{
Jingyu Deng ${ }^{1}$, Han Liang ${ }^{1}$, Guoguang Ying ${ }^{2}$, Qiuping Dong ${ }^{2}$, Rupeng Zhang ${ }^{1}$, \\ Jun $\mathrm{Yu}^{3}$, Daiming Fan ${ }^{4}$, Xishan $\mathrm{Hao}^{1}$ \\ ${ }^{1}$ Department of Gastroenterology, Tianjin Medical University Cancer Hospital, City Key Laboratory of Tianjin Cancer Center \\ and National Clinical Research Center for Cancer, Tianjin, China \\ ${ }^{2}$ Central laboratory, Tianjin Medical University Cancer Hospital, City Key Laboratory of Tianjin Cancer Center and National \\ Clinical Research Center for Cancer, Tianjin, China \\ ${ }^{3}$ Institute of Digestive Disease, Li Ka Shing Institute of Health Science, Chinese University of HongKong, Shatin, HongKong \\ ${ }^{4}$ State Key Laboratory of Cancer Biology and Institute of Digestive Diseases, Xijing Hospital, Fourth Military Medical University, \\ Xi'an, China
}

Correspondence to:

Han Liang, e-mail: tjlianghan@sohu.com

Xishan Hao, e-mail: tjhaoxishan@sohu.com

Keywords: stomach, neoplasm, zinc-finger protein, survival, methylation

Received: November 16, $2014 \quad$ Accepted: December 11, $2014 \quad$ Published: February 26, 2015

\section{ABSTRACT}

Zinc-finger protein 545 (ZNF545) was identified as a gastric tumour suppressor and potentially independent prognostic factor. At the present study, we found that lower expression of ZNF545 was specific in gastric cancer (GC) tissues, and the inconsistently methylated levels of ZNF545 promoter were identified in the gastric cancer tissues. In the methylation-specific PCR (MSP) analysis cohort, we found that GC patients with hypermethylated ZNF545 promoter exhibited significantly shorter median OS than those with unmethylated ZNF545 promoter and those with hypomethylated ZNF545 promoter. In the other cohort, we also demonstrated that GC patients with three or more methylated CpG sites in the ZNF545 promoter were significantly associated with poor survival by using the bisulphite gene sequencing (BGS). The methylated degrees of five CpG sites (-232, $-214,-176,-144$ and -116$)$ could also provide distinct survival discrimination of patients with GC. These findings indicated that the methylated CpG sites of the ZNF545 promoter could be used for the clinical prediction of the prognosis of GC.

\section{INTRODUCTION}

Despite great improvements in traditional diagnosis and treatments, gastric cancer (GC) is accounted for $8 \%$ of all cancer cases and $10 \%$ of all cancer deaths worldwide [1]. GC is highly prevalent in Asia, particularly in China, and considered as one of the leading causes of cancerrelated death in the world [1]. As such, detailed molecular mechanisms involved in the development and progression of GC should be identified and characterised to improve patient prognosis. However, tumour development results from multiple genetic alterations. Similar to other types of cancer, GC develops via a multistage process, including DNA methylation of $\mathrm{CpG}$ islands, post-translational modification of histones, microRNAs and non-coding RNAs and nucleosome positioning [2-5]. Genetic alterations are considered as key tumourigenic events and may be involved in gastric tumourigenesis [6-11]. Promoter methylation is also considered as one of the major mechanisms to inactivate tumour-related genes, particularly tumour suppressor genes, thereby causing gastric carcinogenesis [12]. Therefore, promoter methylation should be considered as an important hallmark of the initiation and progression of GC.

Zinc-finger proteins (ZFPs), among the most common transcription factors in mammals, constitute the largest family of transcriptional regulators in the human genome [13]. Several ZFPs, such as ZNF217 and ZNF639, are oncogenic proteins $[14,15]$, whereas other ZFPs, such as ZAC, ST18, ZNF382 and ZNF331, are tumour suppressors [16-19]. In a previous study, ZNF545 was identified as a gastric tumour suppressor and potentially independent prognostic factor in $79 \mathrm{GC}$ cases [20]. In this study, the methylation degrees of ZNF545 
promoter were detected in 300 GC tissues by qualitative analysis (methylation-specifi PCR, MSP) and in 158 GC tissues by quantitative analyses (bisulphite gene sequencing, BGS) to determine the precise prognostic prediction values of ZNF545 promoter methylation in patients with GC.

\section{RESULTS}

\section{Patient demographics}

The clinicopathological characteristics of the patients and the methylation status of the ZNF545 promoter are listed in Table 1. The median OS of all patients was 21 months, ranging from 2 months to 95 months. Only $61(13.32 \%)$ patients with GC are alive even after follow up was completed.

\section{Protein and mRNA expressions of ZNF545 in 25 GC tissues and 25 normal gastric mucosal tissues}

The mRNA expression of ZNF545 was detected in 25 of the $158 \mathrm{GC}$ tissues and the 25 normal gastric mucosal tissues by RT-PCR (Figure 1A). The relative mRNA expression of ZNF545 in the 25 GC tissues was significantly lower than that in the 25 normal gastric mucosal tissues $(0.321 \pm 0.108$ vs. $1.107 \pm 0.315$, $P<0.001)$. The protein expression of ZNF545 was also simultaneously detected in 25 of the 158 GC tissues and the 25 normal gastric mucosal tissues by western blot (Figure 1B). The relative protein expression value of ZNF545 in the 25 GC tissues was significantly lower than that in the 25 normal gastric mucosal tissues $(0.482 \pm$ 0.116 vs. $1.468 \pm 0.250, P=0.009$ ).

\section{Hypermethylation of the ZNF545 promoter in 300 GC tissues}

We conducted MSP analysis and detected the different degrees of methylation (including hypermethylation, hypomethylation and non-methylation) of the ZNF545 promoter in $300 \mathrm{GC}$ tissues; by contrast, the ZNF545 promoter was not methylated in the 25 normal gastric mucosal tissues (Figure 2). Among the 300 GC tissues, $72(24 \%)$ presented hypermethylated ZNF545 promoter, $61(20.33 \%)$ revealed hypomethylated ZNF545 promoter and 167 (55.67\%) presented with unmethylated ZNF545 promoter.

\section{Methylated CpG sites of the ZNF545 promoter in $158 \mathrm{GC}$ tissues}

The methylated $\mathrm{CpG}$ site count of the 158 patients with GC ranged from 0 to 18 with an average methylated CpG site count of 8.06. Among the 158 patients included in the study, $119(75.32 \%)$ presented one or more methylated CpG sites and 39 (24.68\%) showed no methylated CpG sites.
The patients without methylated $\mathrm{CpG}$ sites exhibited higher median OS than those with one or more methylated $\mathrm{CpG}$ sites (27 months vs. 20 months), but the median OS was not statistically different between the two groups of patients $(P=$ $0.679)$. The result of the cut-point analysis of the methylated CpG site count showed that 82 patients $(51.90 \%)$ exhibited three or more methylated CpG sites and 76 patients (48.10\%) presented two or less methylated $\mathrm{CpG}$ sites. No methylated $\mathrm{CpG}$ sites were found in the normal gastric mucosal epithelial tissues. The images showing the methylated sequences and the charts of $\mathrm{CpG}$ site are shown in Figure 3.

\section{Survival analysis}

In univariate survival analysis, four clinicopathological characteristics were significantly associated with the survival of 300 patients with GC. In MSP analysis, methylated ZNF545 promoter was observed in the same patients. The following characteristics were observed (Table 2): T stage $(P<0.001)$; N stage $(P<0.001)$; location of lymph node metastasis $(P<0.001)$; and gender $(P=0.048)$. Although the methylation of the ZNF545 promoter was significantly associated with the OS of patients, as indicated in KaplanMeier curves $(P<0.001$; Table 2; Figure 4), no statistical survival difference was found between 61 patients with hypomethylated ZNF545 promoter and 167 patients with unmethylated ZNF545 promoter $(P=0.373)$. These factors were included in a multivariate Cox proportional hazard model to adjust the effects of covariates. $\mathrm{N}$ stage $(\mathrm{HR}=$ $1.520, P<0.001)$ and $\mathrm{T}$ stage $(\mathrm{HR}=1.432, P=0.001)$ were identified as the independent predictors of the OS of patients with GC rather than ZNF545 promoter methylation, as revealed by the multivariate survival analysis (Table 2).

In univariate survival analysis, four clinicopathological characteristics were significantly associated with the survival of 158 patients with GC and with methylated ZNF545 promoter (as shown in BGS analysis). The following characteristics were observed (Table 3$)$ : T stage $(P<0.001)$; $\mathrm{N}$ stage $(P<0.001)$; location of lymph node metastasis $(P<0.001)$; and tumour location $(P=0.022)$. The methylated CpG site count $(P=0.034)$, the methylated status of $\mathrm{CpG}$ $-232(P=0.043)$, the methylated status of $\mathrm{CpG}-214$ $(P=0.037)$, the methylated status of $\mathrm{CpG}-176(P=0.022)$, the methylated status of $\mathrm{CpG}-144(P=0.038)$ and the methylated status of $\mathrm{CpG}-116(P=0.027)$ were significantly associated with the OS of patients, as shown in Kaplan-Meier curve discrimination (Table 1; Figure 4). These 10 factors were included in a multivariate Cox proportional hazard model to adjust the effects of covariates. In multivariate analysis, the methylated status of $\mathrm{CpG}-232(\mathrm{HR}=1.490$, $P=0.023), \mathrm{N}$ stage $(\mathrm{HR}=1.659, P<0.001)$ and T stage (HR $=1.659, P=0.001)$ were identified as the independent predictors of the OS of patients with GC after surgery (Table 3 ). In addition, T stage yielded a smaller BIC value than $\mathrm{N}$ stage and the methylated status of $\mathrm{CpG}-232$, representing the optimal prognostic predictor of GC (Table 3). 
Table 1: Patient information

\begin{tabular}{|c|c|c|}
\hline Cohort & 300 patients with MSP analyisis & 158 patients with BGS analysis \\
\hline \multicolumn{3}{|l|}{ Gender } \\
\hline Male & $201(67.00 \%)$ & $112(70.89 \%)$ \\
\hline Female & $99(33.00 \%)$ & $46(29.11 \%)$ \\
\hline \multicolumn{3}{|l|}{ Age at surgery } \\
\hline$\leq 60$ & $181(60.33 \%)$ & $90(56.96 \%)$ \\
\hline$>60$ & $119(39.67 \%)$ & $68(43.04 \%)$ \\
\hline \multicolumn{3}{|l|}{ Tumor size } \\
\hline$<4.0$ & $39(13.00 \%)$ & $27(17.09 \%)$ \\
\hline$\geq 4.0$ & $261(87.00 \%)$ & $131(82.81 \%)$ \\
\hline \multicolumn{3}{|l|}{ Tumor location } \\
\hline Upper third & $69(23.00 \%)$ & $43(27.21 \%)$ \\
\hline Middle third & $81(27.00 \%)$ & $36(22.78 \%)$ \\
\hline Lower third & $131(43.67 \%)$ & $71(44.94 \%)$ \\
\hline More than $2 / 3$ stomach & $19(6.33 \%)$ & $8(5.06 \%)$ \\
\hline \multicolumn{3}{|c|}{ Depth of tumor invasion (T stage) } \\
\hline $\mathrm{T} 1$ & $3(1.00 \%)$ & $2(1.27 \%)$ \\
\hline $\mathrm{T} 2$ & $28(9.33 \%)$ & $19(12.03 \%)$ \\
\hline $\mathrm{T} 3$ & $185(61.67 \%)$ & $98(62.02 \%)$ \\
\hline $\mathrm{T} 4$ & $84(28.00 \%)$ & $39(24.68 \%)$ \\
\hline \multicolumn{3}{|c|}{ Number of metastatic lymph nodes (N stage) } \\
\hline N0 & $80(26.67 \%)$ & $31(19.62 \%)$ \\
\hline N1 & $105(35.00 \%)$ & $57(36.08 \%)$ \\
\hline $\mathrm{N} 2$ & $64(21.33 \%)$ & $43(27.22 \%)$ \\
\hline N3 & $51(17.00 \%)$ & $27(17.08 \%)$ \\
\hline \multicolumn{3}{|c|}{ Location of lymph node metastasis } \\
\hline No & $80(26.67 \%)$ & $31(19.62 \%)$ \\
\hline Perigastric & $95(31.67 \%)$ & $63(39.87 \%)$ \\
\hline Extragastric & $125(41.66 \%)$ & $64(40.51 \%)$ \\
\hline \multicolumn{3}{|l|}{ Lauren classification } \\
\hline Intestinal & $82(27.33 \%)$ & $40(25.32 \%)$ \\
\hline Diffuse & $211(70.33 \%)$ & $107(67.72 \%)$ \\
\hline Mixed & $7(2.34 \%)$ & $11(6.96 \%)$ \\
\hline \multicolumn{3}{|c|}{ ZNF545 promoter methylation (MSP) } \\
\hline Hypermethylation & $72(24.00 \%)$ & - \\
\hline Hypomethylation & $61(20.33)$ & - \\
\hline Non-methylation & $167(55.67 \%)$ & - \\
\hline
\end{tabular}

(Continued) 


\begin{tabular}{|c|c|c|}
\hline \multicolumn{3}{|c|}{ Methylated CpG site count (BGS) } \\
\hline 2 or less & - & $76(48.10 \%)$ \\
\hline 3 or more & - & $82(51.90 \%)$ \\
\hline \multicolumn{3}{|c|}{ Methylated status of $\mathrm{CpG}-232$ (BGS) } \\
\hline Unmethylated & - & $94(59.49 \%)$ \\
\hline Methylated & - & $64(40.51 \%)$ \\
\hline \multicolumn{3}{|c|}{ Methylated status of $\mathrm{CpG}-214$ (BGS) } \\
\hline Unmethylated & - & $84(53.16 \%)$ \\
\hline Methylated & - & $74(46.84 \%)$ \\
\hline \multicolumn{3}{|c|}{ Methylated status of $\mathrm{CpG}-176$ (BGS) } \\
\hline Unmethylated & - & $86(54.43 \%)$ \\
\hline Methylated & - & $72(45.57 \%)$ \\
\hline \multicolumn{3}{|c|}{ Methylated status of $\mathrm{CpG}-144$ (BGS) } \\
\hline Unmethylated & - & $86(54.43 \%)$ \\
\hline Methylated & - & $72(45.57 \%)$ \\
\hline \multicolumn{3}{|c|}{ Methylated status of $\mathrm{CpG}-116$ (BGS) } \\
\hline Unmethylated & - & $96(60.76 \%)$ \\
\hline Methylated & - & $62(39.24 \%)$ \\
\hline
\end{tabular}

\section{Correlation analysis}

Table 4 shows the correlation analysis results between the methylated status of the $\mathrm{CpG}$ sites of the ZNF545 promoter and patient demographics. The methylated status of four $\mathrm{CpG}$ sites $(-214,-176,-144$ and -116$)$ was significantly correlated with the age of the patients with GC subjected to surgery $(P=0.048$, $P=0.010, P=0.024$ and $P=0.002)$. The methylated status of two CpG sites ( -232 and -144$)$ was significantly correlated with the tumour sizes of 158 patients with GC $(P=0.011$ and $P=0.024)$. The methylated status of two $\mathrm{CpG}$ sites $(-214$ and -176$)$ were also correlated with Lauren classification of primary tumour $(P=0.026$ and $P=0.016$ ).

\section{DISCUSSION}

The prognosis of GC is mainly dependent on clinical stage at diagnosis and treatment [21]. DNA methylation is a major mechanism by which tumour suppressor genes are inactivated in many kinds of cancer cells [22]. In human cancers, some ZFPs, including ZAC, ST18, ZNF382 and ZNF331, function as tumour suppressors and are frequently inactivated by $\mathrm{CpG}$ methylation [16-19]. However, other ZFPs are potential oncogenic activators [14, 15]. Tumour suppressor genes involved in cell proliferation are aberrantly inactivated by promoter methylation; this inactivation is frequently involved in multiple processes of tumourigenesis [23]. ZNF545, as a tumour suppressor gene, is potentially downregulated by promoter methylation in multiple tumours, including $13 \mathrm{GC}$ tissues [24]. Cheng et al [24] demonstrated that ZNF545 can repress NF-kB and AP-1 signaling pathways, whereas ectopic ZNF545 expression in silenced tumour cells significantly inhibits tumour growth and induces apoptosis. Functional studies have shown that ZNF545 is involved in ribosome biogenesis by inhibiting rDNA promoter activity and decreasing cellular protein translation efficiency [24]. These findings have indicated that the tumour-specific methylation of ZNF545 can be performed as an epigenetic biomarker to diagnose cancer [24].

In a previous study, ZNF545 participates as a functional tumour suppressor of $\mathrm{GC}$ by inhibiting rRNA transcription; the methylation of ZNF545 is also considered as an independent prognostic factor of 79 patients with GC [20]. Furthermore, ZNF545 is silenced or reduced in GC cell lines and tissues because the promoter was methylated, as revealed by MSP and BGS detection. The ZNF545 promoter is also methylated in $51.9 \%$ of the GC tissues but not in normal gastric mucosal tissues [20]; this result is similar to that in the present study. In the qualitative analysis of methylation, methylated ZNF545 may be regarded as a valuable new prognostic factor of patients with early stage GC [20]. However, we proposed that an optimal prognostic 
GAPDH

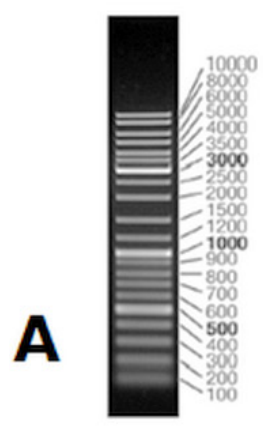

Marker

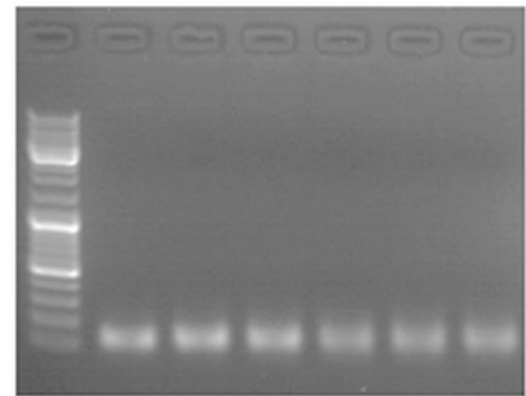

$\begin{array}{lllllll}M & \mathrm{~T} 1 & \mathrm{~N} 1 & \mathrm{~T} 2 & \mathrm{~N} 2 & \mathrm{~T} 3 & \mathrm{~N} 3\end{array}$

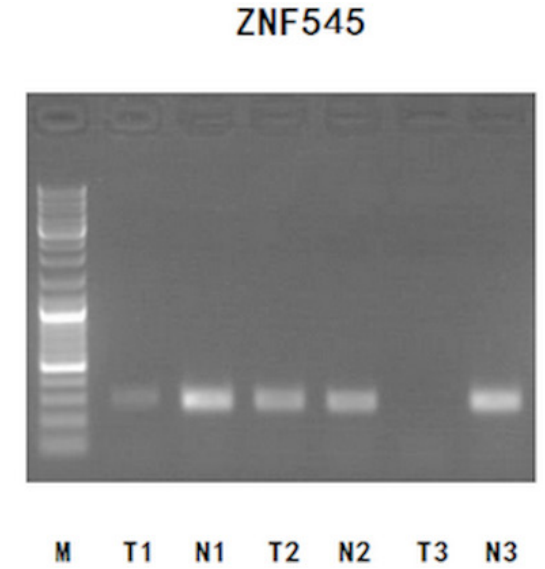

T2

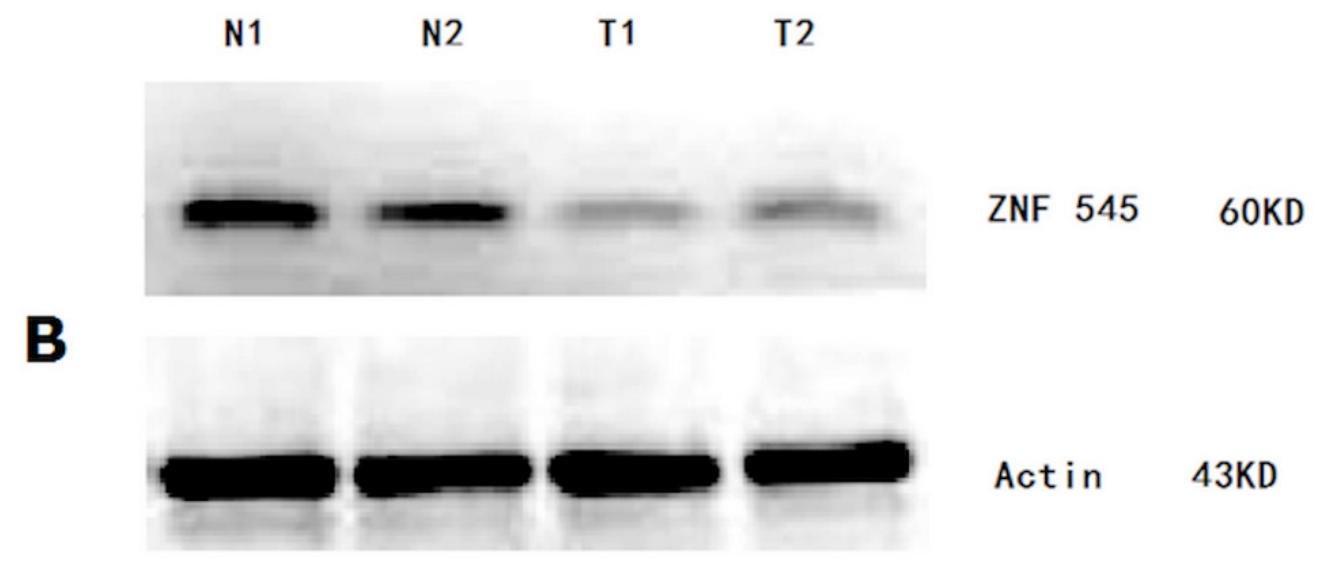

Figure 1: (A) ZNF545 mRNA expression (RT-PCR) in 25 GC tissues and that in 25 normal gastric mucosal tissues; (B) Western Blot analysis for ZNF545 protein expression in $25 \mathrm{GC}$ tissues and that in 25 normal gastric mucosal tissues. (Representation: T, GC tissues; $\mathrm{N}$ : normal gastric mucosal tissues).

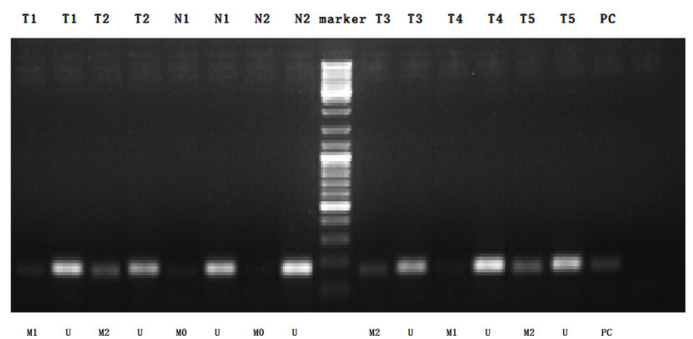

Figure 2: MSP detection of ZNF545 promoter methylation in different GC tissues and normal gastric mucosal tissues. (Representation: T, GC tissues; N, normal gastric mucosal tissues; M0, non-methylation; M1, hypomethylation; M2, hypermethylation; $\mathrm{U}$, unmethylation).

predictor should be detected in patients suffering from all stages of cancer. We detected the mRNA and protein of ZNF545 gene expression in 25 GC tissues and 25 normal gastric mucosal tissues; we also detected significantly lower expression of ZNF545 in GC tissues than in normal gastric mucosal tissues. The methylated ZNF545 promoter was qualitatively detected in 300 GC tissues by conducting MSP analysis. We found that the survival rate of patients with hypomethylated ZNF545 promoter was not significantly different from that of patients with unmethylated ZNF545 promoter; the patients with hypermethylated ZNF545 promoter exhibited shorter OS than the other patients $(P<0.001)$. Therefore, only the hypermethylation of the ZNF545 promoter was significantly associated with the prognostic prediction of GC. 

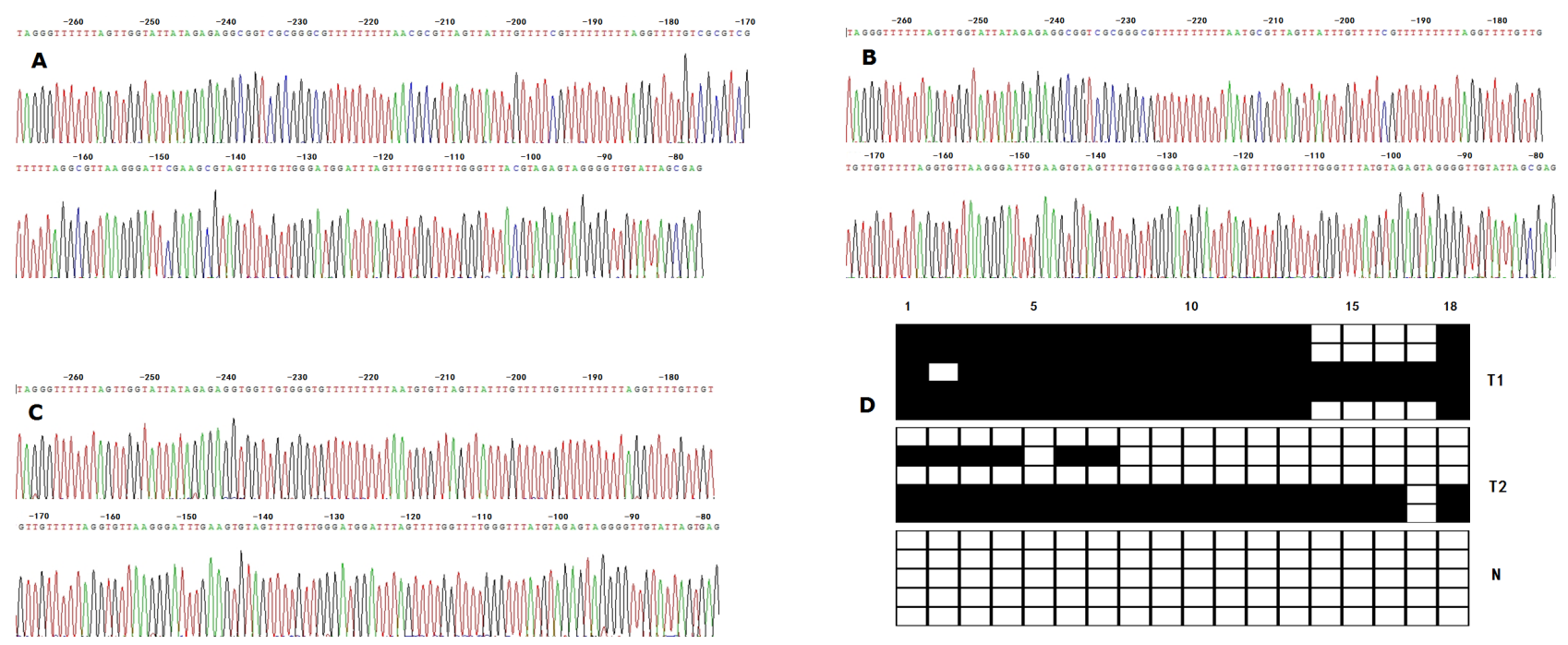

Figure 3: (A) Bisulphite sequencing figure of ZNF545 in GC tissue 1, (B) Bisulphite sequencing figure of ZNF545 in GC tissue 2, (C) Bisulphite sequencing figure of ZNF545 in normal gastric mucosal tissue, and (D) Bisulfite sequencing results in GC tissues and in normal gastric mucosal tissue. (Representation: T, GC tissues; N: normal gastric mucosal tissues).

We performed BGS analysis and quantitatively detected the methylation of ZNF545 promoter in other $158 \mathrm{GC}$ tissues and 25 normal gastric mucosal tissues, including advanced stage GC tissues, to demonstrate the prognostic prediction value of ZNF promoter methylation. Approximately $75.32 \%(119 / 158)$ of the GC tissues contained one or more methylated $\mathrm{CpG}$ sites and none of these sites were found in normal gastric mucosal tissues; this result may indicate that the methylation of ZNF545 promoter is GC specific. We initially failed to demonstrate the statistically prognostic differences between 119 patients with GC and ZNF545 promoter methylation and 39 patients with GC but without ZNF545 promoter methylation. However, differentially methylated $\mathrm{CpG}$ site detection has been used to evaluate the correlation between the methylated levels of gene promoter and various abnormally biological events [25-28]. Therefore, we decided to meticulously analyse the methylated $\mathrm{CpG}$ sites of ZNF545 promoter in 158 patients by using the comparatively quantitative BSP method with no less than five clones of each GC sample [29, 30]. We then demonstrated that patients with GC and with three or more methylated $\mathrm{CpG}$ sites exhibited significantly shorter survival than those with two or less methylated $\mathrm{CpG}$ sites of ZNF545 promoter; this result is consistent with that of the cut-point survival analysis. Five methylated $\mathrm{CpG}$ sites $(-232,-214,-176,-144$ and -116$)$ of the ZNF545 promoter were associated with the OS of 158 patients with GC. Hence, these findings provided relevant information that could be used to further investigate the diagnosis, intervention and prognosis of GC. In multivariate survival analysis (Cox regression with the forward step procedures), the methylated status of $\mathrm{CpG}-232$ of the ZNF545 promoter was considered as an independent prognostic predictor of 158 patients with GC, indicating the importance of ZNF545 promoter methylation.
In contrast to the results of the multivariate survival analysis of 300 patients with GC by conducting MSP detection, our finding of the methylated status of $\mathrm{CpG}-232$ exhibited a smaller BIC value than that of $\mathrm{N}$ stage. This result indicated that this methylated status was the most effective potential prognostic predictor of GC. We also found that the methylated $\mathrm{CpG}$ sites of the ZNF545 promoter were associated with older, larger and diffuse type of GC based on Lauren classification. These clinicopathological characteristics related to the methylated CpG sites of the ZNF545 promoter correspond to the biological behaviours of GC cells, which were discovered in previous studies [20,24].

\section{PATIENTS AND METHODS}

\section{Data source}

After approval from the Tianjin Medical University Cancer Hospital institutional review board, data from the cancer registry of the Tianjin Cancer Institute were obtained. Oral and written informed consents were also obtained from patients who were included in this study. Data obtained from the registry were listed as follows: age, gender, tumour location, tumour size, depth of tumour invasion (T stage, according to the Sixth Edition of UICC TNM Classification for GC), number of metastatic lymph nodes ( $\mathrm{N}$ stage, according to the Sixth Edition of UICC TNM Classification for GC), extent of lymph node metastasis, Lauren classification, and follow-up vital status.

\section{Patients and study samples}

To analyse ZNF545 promoter methylation, we collected 458 fresh GC tissues from patients with GC and 
Table 2: Survival analysis of 300 GC patients with MSP detection of ZNF545 promoter methylation

\begin{tabular}{cccccc}
\hline Variables & $\begin{array}{c}\text { Median OS } \\
(\mathbf{m o})\end{array}$ & $X^{2}$ value & $\begin{array}{c}\text { Univariate } \\
P \text { value }\end{array}$ & HR value & $\begin{array}{c}\text { Multivariate } \\
P \text { value }\end{array}$ \\
\hline
\end{tabular}

\begin{tabular}{|c|c|c|c|c|c|}
\hline \multicolumn{6}{|l|}{ Gender } \\
\hline Male & 23 & 3.922 & 0.048 & & \\
\hline Female & 17 & & & & \\
\hline \multicolumn{6}{|l|}{ Age at surgery (years) } \\
\hline$\leq 60$ & 19 & 0.193 & 0.661 & & \\
\hline$>60$ & 24 & & & & \\
\hline \multicolumn{6}{|l|}{ Tumor location } \\
\hline Upper third & 22 & 1.846 & 0.605 & & \\
\hline Middle third & 16 & & & & \\
\hline Lower third & 24 & & & & \\
\hline$\geq 2 / 3$ stomach & 12 & & & & \\
\hline \multicolumn{6}{|l|}{ Tumor size $(\mathrm{cm})$} \\
\hline$<4.0$ & 26 & 1.054 & 0.305 & & \\
\hline$\geq 4.0$ & 21 & & & & \\
\hline \multicolumn{6}{|l|}{ Lauren classification } \\
\hline Intestinal & 24 & 3.513 & 0.173 & & \\
\hline Diffuse & 20 & & & & \\
\hline Mixed & 24 & & & & \\
\hline \multicolumn{6}{|c|}{ Depth of tumor invasion (T stage) } \\
\hline $\mathrm{T} 1$ & 46 & 21.861 & $<0.001$ & $\begin{array}{c}1.432(1.159- \\
1.769)\end{array}$ & 0.001 \\
\hline $\mathrm{T} 2$ & 25 & & & & \\
\hline $\mathrm{T} 3$ & 24 & & & & \\
\hline $\mathrm{T} 4$ & 14 & & & & \\
\hline \multicolumn{6}{|c|}{ Number of metastatic lymph nodes (N stage) } \\
\hline N0 & 34 & 59.155 & $<0.001$ & $\begin{array}{c}1.520(1.343- \\
1.721)\end{array}$ & $<0.001$ \\
\hline N1 & 23 & & & & \\
\hline $\mathrm{N} 2$ & 17 & & & & \\
\hline N3 & 9 & & & & \\
\hline \multicolumn{6}{|c|}{ Location of lymph node metastasis } \\
\hline No & 34 & 27.942 & $<0.001$ & & \\
\hline Perigastric & 20 & & & & \\
\hline Extragastric & 15 & & & & \\
\hline \multicolumn{6}{|c|}{ ZNF545 promoter methylation } \\
\hline Hypermethylation & 11 & 20.267 & $<0.001$ & & \\
\hline Hypomethylation & 21 & & & & \\
\hline Non-methylation & 25 & & & & \\
\hline
\end{tabular}



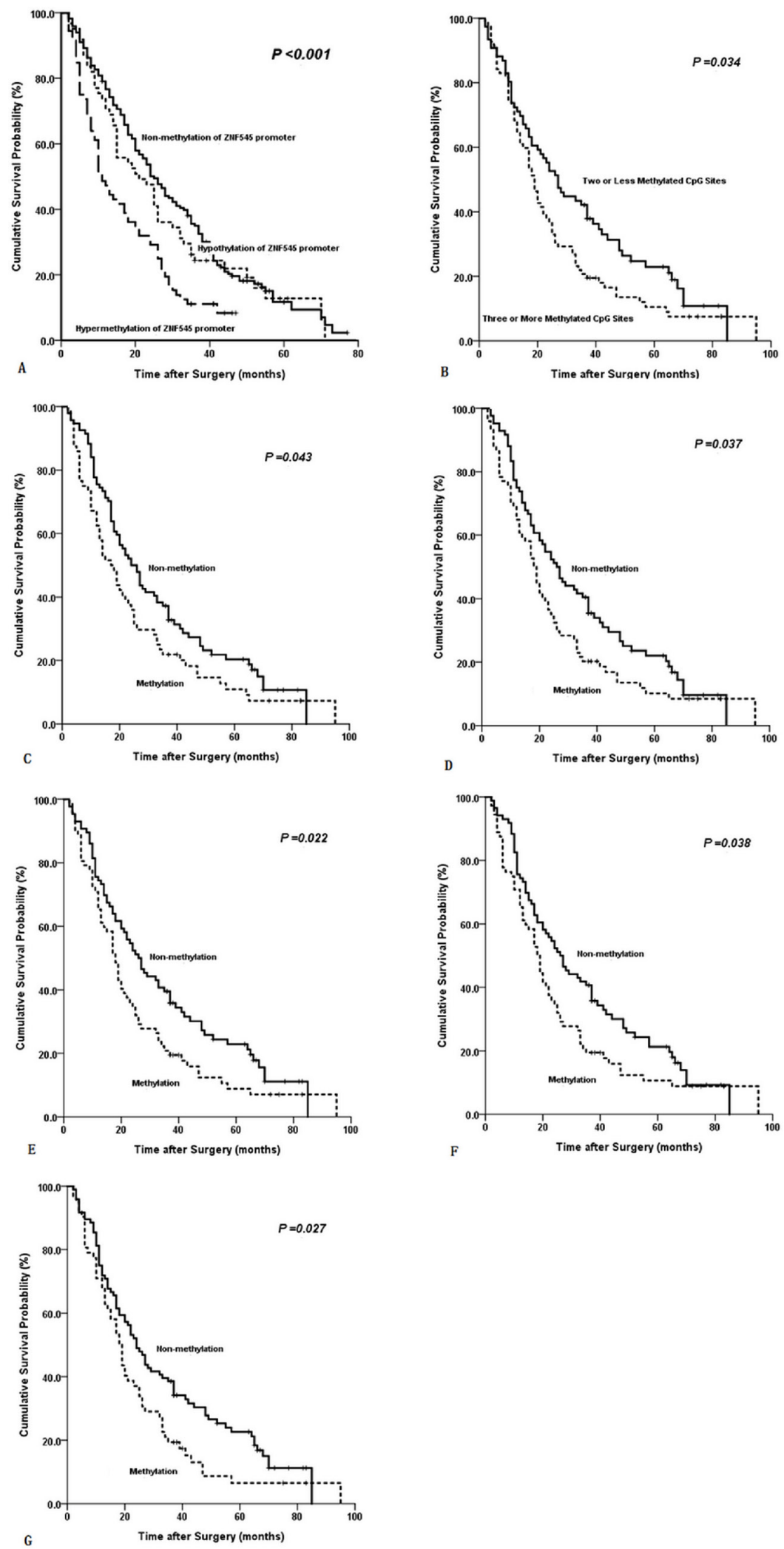

Figure 4: Kaplan-Meier survival curves comparing months of survival in gastric cancer patients are shown for (A) methylated statuses of ZNF545 promoter (MSP), (B) methylated CpG site count of ZNF545 promoter, (C) methylated status of $\mathrm{CpG}-232$, (D) methylated status of $\mathrm{CpG}-214$, (E) methylated status of $\mathrm{CpG}-176$, (F) methylated status of $\mathrm{CpG}-144$, and (G) methylated status of $\mathrm{CpG}-116$. 
Table 3: Survival analysis of 158 GC patients with BGS detection of ZNF545 promoter methylation

\begin{tabular}{lcccccc}
\hline Variables & $\begin{array}{c}\text { Median } \\
\text { OS }(\mathrm{mo})\end{array}$ & $X^{2}$ value & $\begin{array}{c}\text { Univariate } \\
P \text { value }\end{array}$ & HR value & $\begin{array}{c}\text { Multivariate } \\
P \text { value }\end{array}$ & BIC value \\
\hline
\end{tabular}

Gender

Male

Female

\begin{tabular}{|l|l|l|l|}
\hline 20 & 0.911 & 0.340 & \\
\hline 22 & & & \\
\hline
\end{tabular}

Age at surgery (years)

\begin{tabular}{|l|l|l|l|l|l|}
\hline$\leq 60$ & 20 & 0.011 & 0.915 & & \\
\hline$>60$ & 21 & & & & \\
\hline Tumor location
\end{tabular}

Tumor location

\begin{tabular}{|l|l|l|l|l|l|l|}
\hline Upper third & 17 & 9.642 & 0.022 & & & \\
\hline Middle third & 20 & & & & & \\
\hline Lower third & 26 & & & & & \\
\hline$\geq 2 / 3$ stomach & 16 & & & & & \\
\hline
\end{tabular}

Tumor size $(\mathrm{cm})$

\begin{tabular}{|l|l|l|l|l|l|}
\hline$<4.0$ & 27 & 3.040 & 0.081 & & \\
\hline$\geq 4.0$ & 20 & & & & \\
\hline
\end{tabular}

Lauren classification

\begin{tabular}{|l|l|l|l|l|l|l}
\hline Intestinal & 26 & 3.430 & 0.180 & & & \\
\hline Diffuse & 20 & & & & & \\
\hline Mixed & 17 & & & & & \\
\hline
\end{tabular}

Depth of tumor invasion (T stage)

\begin{tabular}{|l|l|l|l|l|l|l|}
\hline $\mathrm{T} 1$ & 70 & 20.677 & $<0.001$ & $1.659(1.224-2.249)$ & 0.001 & 56.968 \\
\hline $\mathrm{T} 2$ & 33 & & & & & \\
\hline $\mathrm{T} 3$ & 23 & & & & & \\
\hline $\mathrm{T} 4$ & 12 & & & & & \\
\hline
\end{tabular}

Number of metastatic lymph nodes (N stage)

\begin{tabular}{|l|l|l|l|l|l|l|}
\hline $\mathrm{N} 0$ & 48 & 43.150 & $<0.001$ & $1.659(1.381-1.993)$ & $<0.001$ & 74.211 \\
\hline $\mathrm{N} 1$ & 25 & & & & & \\
\hline $\mathrm{N} 2$ & 18 & & & & & \\
\hline $\mathrm{N} 3$ & 11 & & & & & \\
\hline
\end{tabular}

Location of lymph node metastasis

\begin{tabular}{|l|l|l|l|l|l|l|}
\hline No & 48 & 23.436 & $<0.001$ & & & \\
\hline Perigastric & 17 & & & & & \\
\hline Extragastric & 18 & & & & & \\
\hline
\end{tabular}

Methylated $\mathrm{CpG}$ site count

\begin{tabular}{|l|r|l|l|l|l|l|}
\hline 2 or less & 27 & 4.497 & 0.034 & & & \\
\hline 3 or more & 19 & & & & & \\
\hline Methylated status of $\mathrm{CpG}-232$ & & & & \\
\hline Unmethylated & 24 & 4.109 & 0.043 & $1.490(1.057-2.099)$ & 0.023 & 68.817 \\
\hline
\end{tabular}

\begin{tabular}{ll} 
(Continued) \\
\hline
\end{tabular} 


\begin{tabular}{|c|c|c|c|c|c|c|}
\hline Variables & $\begin{array}{l}\text { Median } \\
\text { OS (mo) }\end{array}$ & $X^{2}$ value & $\begin{array}{c}\text { Univariate } \\
P \text { value }\end{array}$ & HR value & $\begin{array}{c}\text { Multivariate } \\
P \text { value }\end{array}$ & BIC value \\
\hline Methylated & 17 & & & & & \\
\hline \multicolumn{7}{|c|}{ Methylated status of $\mathrm{CpG}-214$} \\
\hline Unmethylated & 26 & 4.353 & 0.037 & & & \\
\hline Methylated & 18 & & & & & \\
\hline \multicolumn{7}{|c|}{ Methylated status of $\mathrm{CpG}-176$} \\
\hline Unmethylated & 26 & 5.250 & 0.022 & & & \\
\hline Methylated & 18 & & & & & \\
\hline \multicolumn{7}{|c|}{ Methylated status of $\mathrm{CpG}-144$} \\
\hline Unmethylated & 26 & 4.321 & 0.038 & & & \\
\hline Methylated & 18 & & & & & \\
\hline \multicolumn{7}{|c|}{ Methylated status of $\mathrm{CpG}-116$} \\
\hline Unmethylated & 24 & 4.884 & 0.027 & & & \\
\hline Methylated & 18 & & & & & \\
\hline
\end{tabular}

who underwent curative gastrectomy between April 2003 and December 2007 at the Department of Gastroenterology, Tianjin Medical University Cancer Hospital. A cohort of 25 normal gastric mucosal epithelial tissues from normal people was also obtained between 2004 and 2007 at the Department of Endoscopic Examination and Treatment, Tianjin Medical University Cancer Hospital. The tumour and normal gastric mucosal epithelial tissue samples were histologically verified. The patients were not subjected to radiation, chemical or biological treatment before potentially curative gastrectomy was performed. Adjuvant chemotherapy or radiotherapy was not routinely administered to the patients. The clinicopathological characteristics of the two cohorts are summarised in Table 1. Consent regarding the use of tissue samples and records was obtained from each patient. The Institutional Research Ethics Committee of Tianjin Medical University Cancer Hospital approved the study protocol and provided permission to use patient clinical data.

\section{Surgical treatment}

Curative resection was defined as the complete absence of grossly visible tumour tissues and metastatic lymph nodes remaining after resection was performed with pathologically negative resection margins. Primary tumours were resected en bloc with limited or extended lymphadenectomy (D1 or D2-3 according to the Japanese Gastric Cancer Association). Surgical specimens were evaluated according to the Sixth UICC TNM Classification for GC.

\section{DNA and RNA extraction}

Genomic DNA was extracted from the $458 \mathrm{GC}$ tissues and the 25 normal gastric mucosal tissues by using a QIAamp DNA mini kit (Qiagen, Valencia, CA) according to the manufacturer's instructions. Genomic DNA was modified using sodium bisulphite in EZ DNA Methylation-Gold ${ }^{\mathrm{TM}}$ kit (Zymo Research, Hornby, Canada). RNA was extracted from 25 of the $458 \mathrm{GC}$ tissues and 25 normal gastric mucosal tissues by using Trizol reagent (Invitrogen, Carlsbad, CA) according to the manufacturer's instructions.

\section{Western blot and semi-quantitative reverse transcription PCR (RT-PCR)}

A total of 25 of the $458 \mathrm{GC}$ tissues and 25 normal gastric mucosal tissues were each added to $1 \mathrm{~mL}$ of $100 \mathrm{mmol} / \mathrm{L}$ Tris/HCl (pH 7.5), 100 $\mathrm{mmol} / \mathrm{L} \mathrm{NaCl}, 0.5 \%$ sodium deoxycholate, $1 \mathrm{mmol} / \mathrm{L}$ ethylenediaminetetraacetic acid, $1 \%$ Nonidet P-40, $0.1 \%$ sodium dodecyl sulphate and protease inhibitor. After blocking was performed, $50 \mu \mathrm{g}$ of the sample was incubated for $60 \mathrm{~min}$ with rabbit anti-ZNF545 (Santa Cruz, sc-102235, 1:500 dilution) at room temperature. A gel imager system (Asia Xingtai Mechanical and Electrical Equipment Company, Beijing, China) was used to analyse images and determine gray values.

The mRNA expression of ZNF545 was detected by subjecting 25 of the $458 \mathrm{GC}$ tissues and the 25 normal gastric mucosal tissues to RT-PCR. Total RNA was reverse-transcribed to cDNA in a $20 \mu$ l solution by using a reverse transcription kit (Invitrogen, Carlsbad, CA). The primers designed and utilised for ZNF545 were listed as follows: forward sequence 5'-TAAACCCCAAGGAGGACTGAC-3' and reverse sequence 5'-TCCAACATGACATCTCTGTACAAGT-3'. The GAPDH gene was used as an endogenous control of 
Table 4: Correlation analysis between methylated status of CpG sites of ZNF545 promoter and clinicopathological characteristics

\begin{tabular}{|c|c|c|c|c|c|c|}
\hline Variables & $\begin{array}{c}\text { Methylated } \\
\text { CpG sites } \geq 3\end{array}$ & $\begin{array}{c}\text { Methylated } \\
\text { CpG-232 }\end{array}$ & $\begin{array}{c}\text { Methylated } \\
\text { CpG-214 }\end{array}$ & $\begin{array}{c}\text { Methylated } \\
\text { CpG-176 }\end{array}$ & $\begin{array}{c}\text { Methylated } \\
\text { CpG-144 }\end{array}$ & $\begin{array}{c}\text { Methylated } \\
\text { CpG-116 }\end{array}$ \\
\hline \multicolumn{7}{|l|}{ Gender } \\
\hline Male & 60 & 48 & 53 & 54 & 51 & 46 \\
\hline Female & 22 & 16 & 21 & 18 & 21 & 16 \\
\hline$P$ value & 0.511 & 0.348 & 0.849 & 0.298 & 0.989 & 0.462 \\
\hline \multicolumn{7}{|c|}{ Age at surgery (years) } \\
\hline$\leq 60$ & 42 & 31 & 36 & 33 & 34 & 26 \\
\hline$>60$ & 40 & 33 & 38 & 39 & 38 & 36 \\
\hline$P$ value & 0.130 & 0.074 & 0.048 & 0.010 & 0.024 & 0.002 \\
\hline \multicolumn{7}{|l|}{ Tumor location } \\
\hline Upper third & 25 & 23 & 21 & 22 & 23 & 18 \\
\hline Middle third & 18 & 14 & 19 & 17 & 16 & 14 \\
\hline Lower third & 35 & 25 & 31 & 30 & 29 & 27 \\
\hline$\geq 2 / 3$ stomach & 4 & 2 & 3 & 3 & 4 & 3 \\
\hline$P$ value & 0.819 & 0.198 & 0.766 & 0.775 & 0.613 & 0.981 \\
\hline \multicolumn{7}{|l|}{ Tumor size $(\mathrm{cm})$} \\
\hline$<4.0$ & 10 & 5 & 9 & 9 & 7 & 8 \\
\hline$\geq 4.0$ & 72 & 59 & 65 & 63 & 65 & 54 \\
\hline$P$ value & 0.090 & 0.011 & 0.123 & 0.161 & 0.024 & 0.261 \\
\hline \multicolumn{7}{|c|}{ Lauren classification } \\
\hline Intestinal & 23 & 19 & 21 & 21 & 19 & 15 \\
\hline Diffuse & 50 & 39 & 44 & 42 & 45 & 40 \\
\hline Mixed & 9 & 6 & 9 & 9 & 8 & 7 \\
\hline$P$ value & 0.061 & 0.295 & 0.026 & 0.016 & 0.145 & 0.229 \\
\hline \multicolumn{7}{|c|}{ Depth of tumor invasion (T stage) } \\
\hline $\mathrm{T} 1$ & 0 & 0 & 0 & 0 & 0 & 0 \\
\hline $\mathrm{T} 2$ & 9 & 8 & 9 & 8 & 9 & 8 \\
\hline $\mathrm{T} 3$ & 51 & 39 & 45 & 44 & 42 & 38 \\
\hline $\mathrm{T} 4$ & 22 & 17 & 20 & 20 & 21 & 16 \\
\hline$P$ value & 0.452 & 0.669 & 0.551 & 0.513 & 0.381 & 0.701 \\
\hline \multicolumn{7}{|c|}{ Number of metastatic lymph nodes (N stage) } \\
\hline N0 & 16 & 12 & 14 & 14 & 15 & 11 \\
\hline N1 & 30 & 24 & 28 & 26 & 24 & 22 \\
\hline $\mathrm{N} 2$ & 17 & 17 & 17 & 17 & 17 & 15 \\
\hline N3 & 19 & 11 & 15 & 15 & 16 & 14 \\
\hline$P$ value & 0.096 & 0.989 & 0.594 & 0.633 & 0.385 & 0.505 \\
\hline
\end{tabular}

(Continued) 


\begin{tabular}{|c|c|c|c|c|c|c|}
\hline Variables & $\begin{array}{c}\text { Methylated } \\
\text { CpG sites } \geq 3\end{array}$ & $\begin{array}{c}\text { Methylated } \\
\text { CpG-232 }\end{array}$ & $\begin{array}{c}\text { Methylated } \\
\text { CpG-214 }\end{array}$ & $\begin{array}{c}\text { Methylated } \\
\text { CpG-176 }\end{array}$ & $\begin{array}{c}\text { Methylated } \\
\text { CpG-144 }\end{array}$ & $\begin{array}{c}\text { Methylated } \\
\text { CpG-116 }\end{array}$ \\
\hline \multicolumn{7}{|c|}{ Location of lymph node metastasis } \\
\hline No & 16 & 12 & 14 & 14 & 15 & 11 \\
\hline Perigastric & 31 & 22 & 28 & 27 & 28 & 25 \\
\hline Extragastric & 35 & 30 & 32 & 31 & 29 & 26 \\
\hline$P$ value & 0.826 & 0.380 & 0.804 & 0.818 & 0.936 & 0.887 \\
\hline
\end{tabular}

semi-quantitative DNA-PCR. Primers designed and utilised for GAPDH were listed as follows: forward sequence 5'-GAAGGTGAAGGTCGGAGTC-3' and reverse sequence 5'-GAAGATGGTGATGGGATTTC-3'. The following PCR cycling conditions were applied: 35 cycles of denaturation at $95^{\circ} \mathrm{C}$ for $3 \mathrm{~min}$; annealing at $94^{\circ} \mathrm{C}$ for $30 \mathrm{~s}$; and extension at $56^{\circ} \mathrm{C}$ for $30 \mathrm{~s}$; and a final extension at $72^{\circ} \mathrm{C}$ for $8 \mathrm{~min}$. PCR products were electrophoresed on $2 \%$ agarose gel with ethidium bromide and visualised using a gel imager system (Asia Xingtai Mechanical and Electrical Equipment Company, Beijing, China).

\section{Methylation-specific PCR (MSP)}

A total of $300 \mathrm{GC}$ tissues and 25 normal gastric mucosal tissues were subjected to qualitative methylation analysis of the ZNF545 promoter by methylation-specific PCR (MSP). The following ZNF545 primers were used to detect the methylated (M) or unmethylated (U) alleles of the ZNF5 promoter: for methylated alleles, ZNF545MF 5'-GGTATTATAGAGAGGCGGTCGC-3' and ZNF545-MR 5'-ACTCTACGTAAACCCGAAACCG-3'; for unmethylated alleles, ZNF545-UF 5'-AGTT GGTATTATAGAGAGGTGGTTGTG-3' and ZNF545UR 5'-CCTACTCTACATAAACCCAAAACCA-3'. A total of 25 cycles of MSP were performed using Ampli Taq-Gold (methylation-specific primers, annealing temperature $600^{\circ} \mathrm{C}$; unmethylation-specific primers, annealing temperature $580^{\circ} \mathrm{C}$ ). MSP primers were initially evaluated to verify whether or not any unbisulphited DNA is amplified, and the specificity of MSP was further confirmed by directly sequencing some PCR products. PCR was resolved using $2 \%$ agarose gel. Image J software was used to calculate the relative values of the methylation of the ZNF545 promoter in the $300 \mathrm{GC}$ tissues. The hypermethylation of the ZNF545 promoter was defined as the calculated methylated value of GC tissue but not less than the positive control value.

\section{Bisulphite genomic sequencing (BGS)}

The methylation of the ZNF545 promoter in 158 $\mathrm{GC}$ tissues and 25 normal gastric mucosal tissues was qualitatively analysed by BGS. The genomic DNA was modified using sodium bisulphite in an EZ DNA Methylation-Gold ${ }^{\mathrm{TM}}$ kit (Zymo Research, Hornby, Canada). Hot start PCR with bisulphite-treated DNA was performed using a 192 bp PCR product spanning the promoter region from -268 bp to -77 bp relative to the transcription start site of ZNF545. The promoter region of ZNF545 contains 18 $\mathrm{CpG}$ sites. The sequences of the PCR primers were listed as follows: F5'-TAGGGTTTTTTAGTTGGTATTATAGAGAG$3^{\prime}$ and R5'-CTCRCTAATACAACCCCTACTCTAC- ${ }^{\prime}$. The purified PCR products were cloned into the pUC18-T vector (Biodee, Beijing, China), and at least five clones from each sample were randomly selected and sequenced by Shanghai Sangon Co. (Shanghai, China).

\section{Follow up}

After curative surgery, all of the patients were followed up every three months or six months for two years at the outpatient department; these patients were also followed up every year from the third year to the fifth year. Thereafter, these patients were followed up annually until their death. The median follow up of the entire cohort was 41 months, ranging from 1 month to 104 months. The follow up of the patients included in this study was completed in December 2012. Ultrasonography, CT scans, chest X-ray and endoscopy were performed in every visit.

\section{Statistical analysis}

Median overall survival (OS) was determined using Kaplan-Meier method, and log-rank test was performed to determine significance. Potentially important factors in univariate analyses $(P<0.05)$ were included in multivariate analyses. OS was subjected to multivariate analysis by using Cox proportional hazard model with forward step procedures. Hazard ratios (HR) and $95 \%$ confidence interval were calculated. Bayesian information criterion (BIC) in a Cox proportional hazard regression model was calculated in terms of different categories to quantify their discriminatory ability. A small BIC value corresponds to an efficient model to predict outcomes. With cut-point survival analysis, the optimal cutoff of the $\mathrm{CpG}$ site count was 3. Significance was set at $P<0.05$. Statistical analyses were performed using SPSS 18.0. 


\section{ACKNOWLEDGMENTS}

This work was supported in part by grants from the National Basic Research Program of China (973 Program) (NO. 2010CB529301), the Anticancer Special Projects of Tianjin Municipal Science and Technology Commission (NO. 13ZCZCSY20300), and the Special Major Science and Technology of Significant New Drugs Creation (NO. 2013ZX09303001).

\section{Disclosure statement}

The authors have no conflict of interest.

\section{REFERENCES}

1. Jemal A, Bray F, Center MM, Ferlay J, Ward E, Forman D. Global cancer statistics. CA Cancer J Clin. 2011; 61:69-90.

2. Ushijima T, Asada K. Aberrant DNA methylation in contrast with mutations. Cancer Sci. 2010; 101:300-5.

3. Calcagno DQ, Gigek CO, Chen ES, Burbano RR, Smith Mde A. DNA and histone methylation in gastric carcinogenesis. World J Gastroenterol. 2013; 19:1182-92.

4. Tsai KW, Wu CW, Hu LY, Li SC, Liao YL, Lai CH, Kao HW, Fang WL, Huang KH, Chan WC, Lin WC. Epigenetic regulation of miR-34b and miR-129 expression in gastric cancer. Int J Cancer. 2011; 129:2600-10.

5. Ziogas D, Roukos D. Epigenetics in gastric cancer: challenges for clinical implications. Ann Surg Oncol. 2009; 16:2077-8.

6. Zang ZJ, Cutcutache I, Poon SL, Zhang SL, McPherson JR, Tao J, Rajasegaran V, Heng HL, Deng N, Gan A, Lim KH, Ong CK, Huang D, Chin SY, Tan IB, Ng CC, Yu W, Wu Y, Lee M, Wu J, Poh D, Wan WK, Rha SY, So J, Salto-Tellez M, Yeoh KG, Wong WK, Zhu YJ, Futreal PA, Pang B, Ruan Y, Hillmer AM, Bertrand D, Nagarajan N, Rozen S, Teh BT, Tan P. Exome sequencing of gastric adenocarcinoma identifies recurrent somatic mutations in cell adhesion and chromatin remodeling genes. Nat Genet. 2012; 44:570-4.

7. Wang K, Kan J, Yuen ST, Shi ST, Chu KM, Law S, Chan TL, Kan Z, Chan AS, Tsui WY, Lee SP, Ho SL, Chan AK, Cheng GH, Roberts PC, Rejto PA, Gibson NW, Pocalyko DJ, Mao M, Xu J, Leung SY. Exome sequencing identifies frequent mutation of ARID1A in molecular subtypes of gastric cancer. Nat Genet. 2011; 43:1219-23.

8. Jones S, Li M, Parsons DW, Zhang X, Wesseling J, Kristel P, Schmidt MK, Markowitz S, Yan H, Bigner D, Hruban RH, Eshleman JR, Iacobuzio-Donahue CA, Goggins M, Maitra A, Malek SN, Powell S, Vogelstein B, Kinzler KW, Velculescu VE, Papadopoulos N. Somatic mutations in the chromatin remodeling gene ARID1A occur in several tumor types. Hum Mutat. 2012; 33:100-3.
9. Corso G, Velho S, Paredes J, Pedrazzani C, Martins D, Milanezi F, Pascale V, Vindigni C, Pinheiro H, Leite M, Marrelli D, Sousa S, Carneiro F, Oliveira C, Roviello F, Seruca R. Oncogenic mutations in gastric cancer with microsatellite instability. Eur J Cancer. 2011; 47:443-51.

10. Shi J, Yao D, Liu W, Wang N, Lv H, Zhang G, Ji M, Xu L, He N, Shi B, Hou P. Highly frequent PIK3CA amplification is associated with poor prognosis in gastric cancer. BMC Cancer. 2012; 12:50.

11. Shi J, Yao D, Liu W, Wang N, Lv H, He N, Shi B, Hou P, $\mathrm{Ji}$ M. Frequent gene amplification predicts poor prognosis in gastric cancer. Int J Mol Sci. 2012; 13:4714-26.

12. Qu Y, Dang S, Hou P. Gene methylation in gastric cancer. Clin Chim Acta. 2013; 424:53-65.

13. Urrutia R. KRAB-containing zinc-finger repressor proteins. Genome Biol. 2003; 4:231.

14. Cowger JJ, Zhao Q, Isovic M, Torchia J. Biochemical characterization of the zinc-finger protein 217 transcriptional repressor complex: identification of a ZNF217 consensus recognition sequence. Oncogene. 2007; 26:3378-86.

15. Imoto I, Yuki Y, Sonoda I, Ito T, Shimada Y, Imamura M, Inazawa J. Identification of ZASC1 encoding a Kruppel-like zincfinger protein as a novel target for 3q26 amplification in esophageal squamous cell carcinomas. Cancer Res. 2003; 63:5691-6.

16. Kamikihara $\mathrm{T}$, Arima $\mathrm{T}$, Kato $\mathrm{K}$, Matsuda $\mathrm{T}$, Kato $\mathrm{H}$, Douchi T, Nagata Y, Nakao M, Wake N. Epigenetic silencing of the imprinted gene ZAC by DNA methylation is an early event in the progression of human ovarian cancer. Int J Cancer. 2005; 115:690-700.

17. Jandrig B, Seitz S, Hinzmann B, Arnold W, Micheel B, Koelble K, Siebert R, Schwartz A, Ruecker K, Schlag PM, Scherneck S, Rosenthal A. ST18 is a breast cancer tumor suppressor gene at human chromosome 8q11.2. Oncogene. 2004; 23:9295-302.

18. Cheng Y, Geng H, Cheng SH, Liang P, Bai Y, Li J, Srivastava G, Ng MH, Fukagawa T, Wu X, Chan AT, Tao Q. KRAB zincfinger protein ZNF382 is a proapoptotic tumor suppressor that represses multiple oncogenes and is commonly silenced in multiple carcinomas. Cancer Res. 2010; 70:6516-26.

19. Yu J, Liang QY, Wang J, Cheng Y, Wang S, Poon TC, Go MY, Tao Q, Chang Z, Sung JJ. Zinc-finger protein 331, a novel putative tumor suppressor, suppresses growth and invasiveness of gastric cancer. Oncogene. 2013; 32:307-17.

20. Wang S, Cheng Y, Du W, Lu L, Zhou L, Wang H, Kang W, Li X, Tao Q, Sung JJ, Yu J. Zinc-finger protein 545 is a novel tumour suppressor that acts by inhibiting ribosomal RNA transcription in gastric cancer. Gut. 2013; 62:833-41.

21. Hohenberger P, Gretschel S. Gastric cancer. Lancet. 2003; 362:305-15.

22. Jones PA, Baylin SB. The fundamental role of epigenetic events in cancer. Nat Rev Genet. 2002; 3:415-28. 
23. Baylin SB, Ohm JE. Epigenetic gene silencing in cancer a mechanism for early oncogenic pathway addiction? Nat Rev Cancer. 2006; 6:107-16.

24. Cheng Y, Liang P, Geng H, Wang Z, Li L, Cheng SH, Ying J, Su X, Ng KM, Ng MH, Mok TS, Chan AT, Tao Q. A novel 19q13 nucleolar zinc finger protein suppresses tumor cell growth through inhibiting ribosome biogenesis and inducing apoptosis but is frequently silenced in multiple carcinomas. Mol Cancer Res. 2012; 10:925-36.

25. Colaneri A, Wang T, Pagadala V, Kittur J, Staffa NG Jr, Peddada SD, Isganaitis E, Patti ME, Birnbaumer L. A minimal set of tissue-specific hypomethylated CpGs constitute epigenetic signatures of developmental programming. PLoS One. 2013; 8:e72670.

26. Hartley I, Elkhoury FF, Heon Shin J, Xie B, Gu X, Gao Y, Zhou D, Haddad GG. Long-lasting changes in DNA methylation following short-term hypoxic exposure in primary hippocampal neuronal cultures. PLoS One. 2013; 8:e77859.
27. Takahashi T, Matsuda $Y$, Yamashita S, Hattori N, Kushima R, Lee YC, Igaki H, Tachimori Y, Nagino M, Ushijima T. Estimation of the fraction of cancer cells in a tumor DNA sample using DNA methylation. PLoS One. 2013; 8:e82302.

28. Lee YK, Jin S, Duan S, Lim YC, Ng DP, Lin XM, Yeo GSh, Ding C. Improved reduced representation bisulfite sequencing for epigenomic profiling of clinical samples. Biol Proced Online. 2014; 16:1.

29. Vincent A, Ducourouble MP, Van Seuningen I. Epigenetic regulation of the human mucin gene MUC4 in epithelial cancer cell lines involves both DNA methylation and histone modifications mediated by DNA methyltransferases and histone deacetylases. FASEB J. 2008; 22:3035-45.

30. Wang Z, Zheng Y, Hou C, Yang L, Li X, Lin J, Huang G, Lu Q, Wang CY, Zhou Z. DNA methylation impairs TLR9 induced Foxp3 expression by attenuating IRF-7 binding activity in fulminant type 1 diabetes. J Autoimmun. 2013; 41:50-9. 